\title{
Becoming Spatially Embedded: Findings from a Study on Rural Immigrant Entrepreneurship in Norway
}

\author{
Mai Camilla Munkejord
}

\begin{tabular}{|c|c|}
\hline & A B S T R A C T \\
\hline $\begin{array}{l}\text { Objective: } \mathrm{Tl} \\
\text { grant) entre } \\
\text { analysing dat }\end{array}$ & $\begin{array}{l}\text { urpose of this article is to offer a nuanced understanding of (immi- } \\
\text { eurship as a socio-economic and spatially embedded practice by } \\
\text { m a qualitative study in Finnmark, in northernmost Norway. }\end{array}$ \\
\hline $\begin{array}{l}\text { Research De } \\
\text { business visit } \\
\text { lysed using a }\end{array}$ & $\begin{array}{l}\text { \& Methods: The article is based on a qualitative fieldwork including } \\
\text { d in-depth interviews. The transcripts from the interviews were ana- } \\
\text { structivist grounded theory approach (CGT). }\end{array}$ \\
\hline $\begin{array}{l}\text { Findings: The } \\
\text { immigrant er } \\
\text { between imn } \\
\text { immigrants } n \\
\text { literally from }\end{array}$ & $\begin{array}{l}\text { cle contributes to the entrepreneurship literature in general and to the } \\
\text { reneurship literature in particular by investigating mutual connections } \\
\text { nt entrepreneurs, place and community. The article firstly reveals that } \\
\text { e able to successfully create and exploit entrepreneurial opportunities } \\
\text { ne in the rural community in which they settle. }\end{array}$ \\
\hline $\begin{array}{l}\text { Implications } \\
\text { may contribc } \\
\text { increase the } \\
\text { regions. This } \\
\text { younger peo } \\
\text { al variation a }\end{array}$ & $\begin{array}{l}\text { ecommendations: This study notes that immigrant entrepreneurs } \\
\text { building the periphery. Hence, developing our knowledge of how to } \\
\text { ng of local belonging of immigrants may be important for many rural } \\
\text { ecause, rural immigrants not only represent a much needed inflow of } \\
\text { n a typically decreasing and ageing population, but also entail cultur- } \\
\text { ob creation, thus contributing to place development. }\end{array}$ \\
\hline $\begin{array}{l}\text { Contribution } \\
\text { connections } \\
\text { how immigra } \\
\text { cessfully cre } \\
\text { through entr }\end{array}$ & $\begin{array}{l}\text { Value Added: The originality of this article is to investigate mutual } \\
\text { ween immigrant entrepreneurs, place and community, hence revealing } \\
\text {, when being supported by the rural community, may be able to suc- } \\
\text { and exploit entrepreneurial opportunities in rural communities, and, } \\
\text { eneurship processes, may even contribute to (re)build the rural areas. }\end{array}$ \\
\hline Article type: & research paper \\
\hline Keywords: & $\begin{array}{l}\text { immigrant entrepreneurship; local community; Northern Norway; } \\
\text { rural context; spatial embeddedness }\end{array}$ \\
\hline JEL codes: & $\mathrm{J} 15, \mathrm{~F} 22, \mathrm{~L} 26$ \\
\hline Received: $9 \mathrm{~S}$ & Revised: 15 December 2016 \\
\hline
\end{tabular}

\section{Suggested citation:}

Munkejord, M.C. (2017). Becoming Spatially Embedded: Findings from a Study on Rural Immigrant Entrepreneurship in Norway. Entrepreneurial Business and Economics Review, 5(1), 111-130, DOI: http://dx.doi.org/10.15678/EBER.2017.050107 


\section{A Glimpse Into the Field}

Daniela ${ }^{1}$ is a professional glass blower from Switzerland who runs Arctic Glasstudio in the small fishing village of Berlevåg, Finnmark. Since 1996, she and her employee(s) have produced and sold glass decoration articles of high artistic quality that are inspired by the landscapes and multicultural history of the rural north.

When I asked her why she established her workshop and store in this peripheral community, she immediately referred to the overwhelming response she received to her first small production of colourful glass balls for Christmas in 1989. At that time, Daniela and her husband Dieter had recently settled in Finnmark and were going through tough economic times. Daniela had not yet been granted a work permit, and the job Dieter had initially been offered upon their relocation in the north did not materialize due to a major fishery crisis that autumn (known as the "cod moratorium"). However, their economic troubles evaporated when Daniela decided to make glass balls for Christmas using some simple equipment she had brought when heading north:

Daniela: You know, I had brought some residual glass tubes from Switzerland, my table burner and blowtorch, so I just had to get hold of some propane and a bottle of oxygen, which I got from the hydraulics. Then, I organized a small glassblowing workshop in the kitchen, and I blew some glass balls in various colours. They became really popular!

Mai: How many did you make?

Daniela: I made a few hundred. They were sold at the local petrol station, and they just disappeared! And what was perhaps even more curious was that people sent them out to family and friends living elsewhere in the country with the greeting, 'Look, this is made in Berlevåg!'

Mai: So people here were proud?

Daniela: Yes, they were proud! And this experience really started a good relationship with people in the community here.

Daniela explained that from day one in Berlevåg, she and her husband Dieter have experienced substantial support from people in the community for their various activities and engagements. As of the interview, Daniela ran the glass studio, and her husband Dieter ran the tourism office, the camping and the guesthouse in the locality. People in the community, Daniela explained, did 'everything they could' to make sure that she and Dieter felt at home and that they were included in various social gatherings. She said that everyone came to her store to buy things, adding, 'I guess there is no community in the world with more glass decoration articles in the homes than here in Berlevåg!'

\section{INTRODUCTION}

This article investigates the significance of spatial embeddedness in entrepreneurship processes. Based on field visits and in-depth interviews with Daniela and 14 other immigrant entrepreneurs in the peripheral context of Finnmark, in northernmost Nor-

\footnotetext{
${ }^{1}$ The case about Daniela, Dieter, the camping and the glass studio is not anonymized according to their own preference. All the other cases are anonymized.
} 
way, I analyse the mutual engagements between immigrant entrepreneurs, place and community. In fact, spatial embeddedness is increasingly recognized as an essential factor in understanding and explaining entrepreneurial processes (Anderson, 2000; Kalantaridis, 2006; McKeever, Jack, \& Anderson, 2015; Riley, 2000; Welter, 2011). According to this perspective, entrepreneurs are embedded in places in ways that shape how they perceive and construct resources and opportunities.

In particular, (some of) the literature assumes that long-term residence in a certain place and deep social relations with the community might be key to entrepreneurial success (Dahl \& Sorenson, 2007; Jack \& Anderson, 2002; McKeever, Anderson, \& Jack, 2014). Dahl and Sorenson (2007, p. 3), for instance, indicate that entrepreneurs 'have the greatest odds of success in their 'home' regions - those in which they have long histories and deep social connections.' McKeever, Anderson, \& Jack (2014) support this perspective by arguing that close familiarity with local ways of doing business might facilitate entrepreneurial processes and strengthen outcomes, particularly in rural areas. This leads to the supposition that entrepreneurial opportunities are created and exploited more naturally or effectively 'by locals within the structure to which they belong than by outsiders or newcomers' (McKeever, Anderson, \& Jack, 2014, p. 457).

These may be reasonable and well-founded assumptions. However, through the study of spatial embeddedness of entrepreneurial practices among immigrants in northernmost Norway, this article shows that connections among entrepreneurs, places and communities may be established in various ways. To investigate these issues, this article explores the following research question: How do immigrant entrepreneurs engage with place and community in a rural context? I draw on literature on community (Halfacree, 1995, 2004; Panelli, 2006) and embeddedness (Granovetter, 1985; McKeever, Jack \& Anderson, 2015; Uzzi, 1997), and employ a qualitative approach that includes field visits and in-depth interviews with 15 purposefully selected participants living and operating in Finnmark, in northernmost Norway.

Immigrant entrepreneurship has been developed as a field of study over a long period of time (Aldrich \& Waldinger, 1990; Dana, 2007; Jones, Ram, \& Theodorakopoulos, 2010; Kloosterman \& Rath, 2001; Morawska, 2004; Portes \& Jensen, 1989; Portes \& Zhou, 1996; Ram \& Jones, 2008; Waldinger, 1994). However, we still know little about rural immigrant entrepreneurship, a few exceptions apart (Kalantaridis, 2010; Smart, 2003; Steinberg, et al., 2010; Stone \& Stubbs, 2007; Zarrugh, 2007). Moreover, Yeasmin (2016) has recently published a study on nascent, current and former immigrant entrepreneurs in Lapland, rural Finland. She argues that immigrant entrepreneurs in rural areas face multiple disadvantages, and she used a triple disadvantage theory to explain how, in her view, this is the case (Yeasmin, 2016). Hence, Yeasmin argues that a) immigrant (contrary to native) entrepreneurs in rural Finland are 'forced to establish businesses due to social barriers', b) immigrant (contrary to native) entrepreneurs in rural Finland are unable 'to take advantage of knowledge spillover' due to e.g. poor language skills and limited knowledge about the local culture and c) the rural region where the immigrants have settled represents a disadvantage because 'the market of ethnic consumers is small' there (Yeasmin, 2016, pp. 133-134). While Yeasmin's argument has some value, this article will reveal that the triple disadvantage perspective is not neces- 
sarily valuable to make sense of the experiences of immigrant entrepreneurs in rural parts of the Nordic countries in general. I will come back to this issue in the conclusions.

This article advances our understanding of entrepreneurial embeddedness in several ways. First, it reveals that immigrants who barely know the local language may be able to successfully create and exploit entrepreneurial opportunities literally from day one in the rural community in which they settle. According to the immigrant entrepreneurs, the rural community itself plays a key role in this process. Upon their arrival, the nascent immigrant entrepreneurs are, of course, unfamiliar with local ways of doing business in the rural north, but they reported that their mishaps were forgiven, and that the local population sometimes even assisted them to successfully establish and develop their business. Second, and following the first point, spatial embeddedness through social relations is crucial to the entrepreneurial processes in the light of this study. However, in contrast to previous research, I show that social relations in a local community do not have to be long term or deep to act as a link to various local social resources. Instead, social ties may be established between persons in the local community and immigrants directly upon the newcomers' arrival. This may be even more pronounced in the case of remote and perhaps depleted communities in which in-migration in general and entrepreneurship in particular are desired. Third, this study indicates that rural immigrant entrepreneurs may be able to rebuild the rural areas. Thus, although long-term residence and deep social ties may strengthen the embedding processes of various entrepreneurs in local structures, they are not a precondition for identifying and exploiting entrepreneurial opportunities.

The remainder of this paper proceeds as follows. First, I present the relevant literature used in this paper. Next, I present the study's qualitative methodology, including data collection, analysis and the sample, as well as the choice of the geographical context. Thereafter, I present and analyse the findings before concluding and giving suggestions for future research.

\section{LITERATURE REVIEW}

Although entrepreneurship research has traditionally focused on the identification and exploitation of opportunities as an individualized and economic pursuit, an increasing body of literature investigates entrepreneurship as a socio-spatial process (Anderson, 2000; Brown, 2000; Jack \& Anderson, 2002; McKeever, Jack \& Anderson, 2015; Riley, 2000; Steyaert \& Katz, 2004; Welter, 2011; White, 2004; Xheneti, Smallbone, \& Welter, 2013). Hence, entrepreneurship is more and more viewed as a 'process contextually based in local communities' (McKeever, Anderson, \& Jack, 2014, p. 455). Moreover, how women and men construct opportunities and whether and how they choose to act upon them are influenced by many factors, such as their background, identity, education, their social capital including access to various resources, and how they engage with the place(s) where they live (Storti, 2014).

Places are complex systems of materiality and sociality that offer certain possibilities and constraints (Berg \& Dale, 2004; Massey, 1994). Place in this paper is hence conceptualized both as a geographical and material location and as social relations of women and men living there (Massey, 1994). Business location decisions may be influenced by belonging or attachment to place (Dahl \& Sorenson, 2009; Stone \& Stubbs, 2007). In this paper, social aspects of place and how immigrants relate to place, will be examined by focusing on the role of the local community. The rural sociologist Panelli emphasizes that 'as a mid-scale concept, community has been used to address the structural, relational 
(and in some cases spatial) dimensions of a social grouping that is popularly and politically recognized between the family and regional or national groups' (Panelli 2006, 68). The local community is not a uniform or stable phenomenon (Liepins, 2000), but can be used as an analytical concept that draws attention to the situations and contexts in which enactment with people living in a certain locality are investigated.

In this article, I am particularly concerned with how immigrants engage with place and community in Finnmark through entrepreneurship and, in turn, how the community, according to the participants, engages with them. To address this issue, I employ the concept of embeddedness, which is increasingly used to refer to the manner in which economic practices - such as entrepreneurship - are contingent with respect to cognition, culture, social structure or institutions (Uzzi, 1997, p. 36). Embeddedness refers to the mechanism whereby an entrepreneur becomes part of local social structures (Jack \& Anderson 2002; Granovetter, 1985; Kalantaridis \& Bika, 2006). In particular, the term highlights the mutual process whereby an immigrant entrepreneur links into social relations and local structures in the rural community in which he/she has settled and the manner in which the community engages with or embraces the immigrant entrepreneur. Uzzi (1997, 37, referencing Romo and Schwartz 1995) argues that embedded actors in regional production 'shift their focus from the narrow economically rational goal of winning immediate gain (...) to cultivating long-term cooperative ties'. Moreover, Uzzi finds that embedded relationships have three main components that regulate the expectations and practices of the partners involved: trust, fine-grained information transfer and joint problem arrangements (Uzzi, 1997, 42-47): Trust requires that the entrepreneur is confident that the partner would not act solely out of self-interest and assumes the best when interpreting the partner's motives and practices. Likewise, fine-grained information transfer refers to the sharing of important information, such as strategy and tacit information about local ways of doing business. Joint problem arrangements involve mutual adjustments and assisting in finding a solution when a problem or challenge occurs.

Thus, the concept of embeddedness, as developed by Uzzi (1997) and others, is important because it provides knowledge about local values and enables the entrepreneur to identify and use local resources to create or exploit business opportunities. The concept emphasizes entrepreneurship as a social and spatial process and may explain how engagement with place and community can shape various perceptions and enactments of opportunities among differently situated entrepreneurs (McKeever, Jack \& Anderson, 2015).

\section{MATERIAL AND METHODS}

A qualitative, interpretative approach was thought to be most appropriate for this study to provide a better understanding of various dimensions of the spatial embeddedness of entrepreneurship processes (Charmaz, 1995; Gartner, 2007). Narratives are frequently used within interpretative methodologies to explore how individuals comprehend their everyday life situations because telling their stories enables individuals to draw on memory and current experience and to bridge the past and the present (Cohen \& Rapport, 1995). In the following, I will begin by presenting the context of this study before discussing the data collection methods, the sample and the analytical procedures. 


\section{The Peripheral / Rural Context of Finnmark}

Finnmark offers an evocative locus for this study. Despite its vast area (48 637 square kilometres), only 75000 people live in the Finnmark region, resulting in a population density of less than two persons per $\mathrm{km}^{2}$. The region is located between 70 and 71 degrees north. The majority of people live along the coast in small towns and fishing villages. Fisheries have long played a crucial role in the region, along with small-scale peasant farming. Within the national context of Norway, Finnmark as the rest of northern Norway was long represented in public records as a 'suppressed and exploited backyard' and within a perspective of 'victimization and subordination'(Kraft, 2008, p. 222). More recently, however, other dimensions of the rural north have been highlighted. It is for instance argued that many places in Finnmark seem to have what she terms a coastal rural competence in coping with change, entailing a "particular sense of inclusiveness, open gendered spaces, and flexible place identities" (Munkejord, 2014, p. 38). Although Finnmark still relies on the primary sector and has a low population size and density, various changes are occurring in the region. First, transport improvements and communication technologies have reduced travel time and the sense of distance among the inhabitants in the region. Second, the area is undergoing a re-industrialisation process with the establishment of the petroleum industry in Hammerfest in 2002 and the re-establishment of the mining industry in Kirkenes in 2009. Hence, skilled employment has become increasingly important to both industrial mega-projects and to the public welfare sector. Third, after decades of decline, Finnmark's population has stabilized since 2007 and has even begun to show an upward trend. This growth is primarily due to national and international in-migration to the four largest towns in Finnmark. There are currently 6773 immigrants in Finnmark, originating from Russia, Finland, Poland, Lithuania and Sweden as well as Somalia, Thailand and other countries. Hence, the number of international in-migrants is increasing, as is the number of immigrant firms (Special Tables Statistics Norway). Whereas immigrants who arrive in the US, Canada, Australia or the UK can frequently choose to become part of large ethnic communities, this is not the case in the thin and scattered population of Finnmark as dicussed in (Munkejord, 2015a).

\section{Fieldwork in Finnmark}

Fieldwork was conducted in Finnmark in 2012 and included business visits and semistructured in-depth interviews with immigrant women and men who had started their own businesses and hence were self-employed. At the time of data collection, I had lived in Finnmark for 8 years and was therefore quite familiar with some of the local communities in which the selected participants had settled. I identified some of the participants through my personal networks, and others through social media and contact persons in business associations and in the municipal administration of the selected field sites. In total, there were 170 immigrant entrepreneurs in Finnmark at the time of the interview (special table, Statistics Norway). I initially decided to get in touch with approximately 30 of these, aiming at interviewing participants of various ages and of various migration backgrounds in order to reflect the greater picture of immigrant entrepreneurs in this particular region. I used personal contacts and the snowball method to identify potential informants, and ended up with interviewing 20 women and 9 men purposefully selected on the basis of their education, family situation and business sector. All participants gave their informed consent. 
In the interviews, I questioned the participants about their upbringing, education, previous work experience and migration history, and asked them to share their new everyday life experiences in the north with an emphasis on family, business, community and place. Most of the interviews took place at the participants' workplaces, although some preferred to be interviewed at home or in a café. The interviews were generally conducted in Norwegian because most participants spoke the Norwegian language very well, whereas a couple of the interviews were conducted partly in English. The interviews lasted from 35 to 130 minutes, with an average of 75-80 minutes. In addition, we frequently had an introductory chat over a cup of coffee, and in many cases, I visited the business premises. I conducted and transcribed the interviews myself.

\section{Data analysis by Use of Constructivist Grounded Theory}

The transcripts were thematically analysed using a constructivist grounded theory (CGT) approach (Charmaz, 1995). Charmaz (1995) recommends two phases of coding. The first is an initial line-by-line coding (naming each line of the data material). This helps in assuming an analytic stance towards the interview material while remaining close to the data to understand what the participants are saying. The initial line-by-line coding was accomplished partly during the data collection period, which helped me to direct my focus in the next interviews. The second phase consists of focused coding, which is more directed and conceptual and aims to establish and try out categories for capturing the data in relation to various research questions (Charmaz 1995, p. 40). In the second round of coding for this article, I conducted a systematic analysis of the interviews to identify statements about the mutual connections between immigrant entrepreneurs, place and community.

\section{The Sample: Background Information About the Participants}

For the purpose of this article (Table 1), I have analysed the stories of 15 immigrant entrepreneurs, six refugees and nine 'lifestyle migrants' (O'Reilly \& Benson, 2009). The refugees, with one exception, did not initially select Finnmark as a region of particular attraction but were settled there by Norwegian authorities after obtaining a residence permit. After completing the 2-year compulsory introductory programme, however, they decided to remain in the north. The lifestyle migrants, on the other hand, who came from Western Europe or from Russia, had moved to Finnmark because they desired to experience something 'different' and 'exotic' or 'arctic'. Both the refugees and the lifestyle migrants were primarily married with a partner from their country of origin. The 15 participants, six women and nine men, comprised 11 households. The informants had started a number of businesses, including a garage, an architectural firm, a painting company, a spa, cafes, restaurants and shops, and firms providing massage therapy and acupuncture as well as a nature-based tourism firm. Some of the participants ran several (related) firms. The businesses varied in terms of their size, income provision, and the hours that the entrepreneurs worked, but in general, the firms were very small, with 0-10 employees.

To preserve confidentiality, the names are fictitious and the ages given are approximate. It should be noted that although I have spoken to several members of the local population in various communities in Finnmark about different aspects of immigrant entrepreneurship, the analysis in this article is based solely on my interviews with the immigrant entrepreneurs. 
Table 1. Overview of respondents

\begin{tabular}{|c|c|c|c|c|c|c|c|c|}
\hline $\begin{array}{l}\text { Respond- } \\
\text { ents }\end{array}$ & $\begin{array}{l}\text { Migration \& family } \\
\text { situation }\end{array}$ & $\begin{array}{l}\text { Time in rural } \\
\text { bef. start-up }\end{array}$ & Business & $\begin{array}{l}\text { Time in } \\
\text { rural }\end{array}$ & Children & $\begin{array}{l}\text { Role of } \\
\text { spouse }\end{array}$ & $\begin{array}{l}\text { Why becoming } \\
\text { entrepreneur? }\end{array}$ & Background and experience \\
\hline $\begin{array}{l}\text { Daniela } \\
\text { (50) }\end{array}$ & $\begin{array}{l}\text { Married to Dieter, } \\
\text { both lifestyle } \\
\text { migrants from } \\
\text { Switzerland. They } \\
\text { are copreneurs. }\end{array}$ & $\begin{array}{l}\text { First } \\
\text { production: } \\
\text { just after } \\
\text { arrival. } \\
\text { Glasstudio: } \\
\text { after } 8 \text { years. } \\
\text { After } 1 \text { year: } \\
\text { tourism office } \\
\text { and, later, } \\
\text { camping and } \\
\text { guest house } \\
\end{array}$ & $\begin{array}{l}\text { She: Arctic } \\
\text { Glasstudio } \\
\text { He: Camping } \\
\text { and guest } \\
\text { house }\end{array}$ & 23 yrs & - & Full partner & $\begin{array}{l}\text { Never the plan, } \\
\text { but got the } \\
\text { opportunity in } \\
\text { Finnmark, } \\
\text { meaningful }\end{array}$ & $\begin{array}{l}\text { She: professional glassblower. After } \\
\text { arriving in Finnmark together with Dieter, } \\
\text { worked in the fish processing industry } \\
\text { and later ran a café. She currently runs } \\
\text { Arctic Glasstudio, producing and selling } \\
\text { artefacts of glass. He: engineer. After } \\
\text { settling in Finnmark, started a local } \\
\text { tourism office; still runs this + the } \\
\text { camping and guest house. They have } \\
\text { taken courses in entrepreneurship and } \\
\text { business (gründer school). }\end{array}$ \\
\hline $\begin{array}{l}\text { Hans } \\
\text { and } \\
\text { Hilda } \\
\text { (55) }\end{array}$ & $\begin{array}{l}\text { Lifestyle migrants } \\
\text { and copreneurs } \\
\text { from Western- } \\
\text { Europe }\end{array}$ & At arrival & $\begin{array}{l}\text { Café offering } \\
\text { local food }\end{array}$ & 3 yrs & (adult) & Full partner & $\begin{array}{l}\text { Doing something } \\
\text { meaningful, } \\
\text { creating pride in } \\
\text { local food }\end{array}$ & $\begin{array}{l}\text { Both of them have degrees in } \\
\text { economics. They worked as self- } \\
\text { employed economic consultant before } \\
\text { migrating to Finnmark. They developed } \\
\text { the concept of the café and the menu } \\
\text { in close collaboration with locals. }\end{array}$ \\
\hline $\begin{array}{l}\text { Vibeke } \\
\text { and Vidar } \\
\text { (35) }\end{array}$ & $\begin{array}{l}\text { Lifestyle migrants } \\
\text { and copreneurs } \\
\text { from Western- } \\
\text { Europe }\end{array}$ & After 6 yrs & $\begin{array}{l}\text { Architectural } \\
\text { firm, } \\
\text { including } \\
\text { landscape } \\
\text { architecture }\end{array}$ & $10 \mathrm{yrs}$ & $\begin{array}{l}2 \\
\text { children, } \\
\text { kindergar } \\
\text { ten }\end{array}$ & Full partner & $\begin{array}{l}\text { Autonomy, to } \\
\text { contribute to } \\
\text { place } \\
\text { development / } \\
\text { make a } \\
\text { difference in the } \\
\text { North, and to } \\
\text { have an } \\
\text { opportunity to } \\
\text { be creative }\end{array}$ & $\begin{array}{l}\text { Both have degrees in architecture. Both } \\
\text { were employed as architects in } \\
\text { Finnmark before taking over and } \\
\text { developing their architectural firm. They } \\
\text { have approximately ten employees and } \\
\text { they run several local community } \\
\text { projects. }\end{array}$ \\
\hline $\begin{array}{l}\text { Eeva } \\
(30)\end{array}$ & $\begin{array}{l}\text { Lifestyle migrant } \\
\text { and entrepreneur } \\
\text { from Western } \\
\text { Europe, married to } \\
\text { a Norwegian }\end{array}$ & After 5 yrs & $\begin{array}{l}\text { Paint and } \\
\text { surface } \\
\text { decoration } \\
\text { firm }\end{array}$ & 10 yrs & $\begin{array}{l}2 \\
\text { children, } \\
\text { kindergar } \\
\text { ten and } \\
\text { school }\end{array}$ & $\begin{array}{l}\text { Initially of } \\
\text { great } \\
\text { support, } \\
\text { now also } \\
\text { employed in } \\
\text { the firm } \\
\end{array}$ & $\begin{array}{l}\text { Autonomy, } \\
\text { flexibility, doing } \\
\text { something } \\
\text { "challenging", } \\
\text { "nice" and } \\
\text { "stable" }\end{array}$ & $\begin{array}{l}\text { Eeva has a craft certificate } \\
\text { ("mesterbrev") in painting and surface } \\
\text { treatments. She worked in the fishing } \\
\text { industry in Finnmark and later as } \\
\text { a painter before starting her own } \\
\text { business. }\end{array}$ \\
\hline
\end{tabular}




\begin{tabular}{|c|c|c|c|c|c|c|c|c|}
\hline $\begin{array}{l}\text { Vladimir } \\
\text { and } \\
\text { Villia } \\
\text { (40) }\end{array}$ & $\begin{array}{l}\text { Lifestyle migrants } \\
\text { from Russia. He is } \\
\text { the entrepreneur. }\end{array}$ & After 11 yrs & $\begin{array}{l}\text { Nature- } \\
\text { based } \\
\text { tourism firm }\end{array}$ & 12 yrs & $\begin{array}{l}2 \\
\text { children, } \\
\text { kindergar } \\
\text { ten and } \\
\text { school }\end{array}$ & $\begin{array}{l}\text { Of great } \\
\text { support } \\
\text { (emotionally } \\
\text { and } \\
\text { practically) }\end{array}$ & $\begin{array}{l}\text { Being outdoors } \\
\text { in the nature, } \\
\text { sharing the } \\
\text { fascinating arctic } \\
\text { landscape with } \\
\text { interested } \\
\text { tourists }\end{array}$ & $\begin{array}{l}\text { Both have university degrees from } \\
\text { Russia. He has long worked in } \\
\text { Finnmark, employed in a firm offering } \\
\text { nature-based tourism experiences such } \\
\text { as ice diving, fishing, and king crab } \\
\text { safari. He is in the start-up phase of his } \\
\text { own nature-based tourism firm } \\
\text { targeting the upper class Russian } \\
\text { market. During the start-up phase, } \\
\text { Villia assisted him a lot. She recently } \\
\text { obtained a new job in the private } \\
\text { sector. }\end{array}$ \\
\hline $\begin{array}{l}\text { Lars } \\
(45)\end{array}$ & $\begin{array}{l}\text { Lifestyle migrant } \\
\text { together with his } \\
\text { wife from Western } \\
\text { Europe. He is the } \\
\text { entrepreneur. }\end{array}$ & At arrival & $\begin{array}{l}\text { Acupuncture } \\
\text { / Chinese } \\
\text { medicine }\end{array}$ & $10 \mathrm{yrs}$ & $\begin{array}{l}3 \\
\text { children, } \\
\text { kindergar } \\
\text { ten and } \\
\text { school }\end{array}$ & $\begin{array}{l}\text { Of great } \\
\text { support. At } \\
\text { times main } \\
\text { breadwinner } \\
\text { and care } \\
\text { taker in the } \\
\text { home }\end{array}$ & $\begin{array}{l}\text { Autonomy, } \\
\text { meaningful to } \\
\text { help others } \\
\text { through } \\
\text { acupuncture }\end{array}$ & $\begin{array}{l}\text { Both have university degrees from } \\
\text { their country of origin. They originally } \\
\text { came to Finnmark for a year to } \\
\text { experience something different, but } \\
\text { later decided to stay. He started his } \\
\text { firm shortly upon their arrival. She } \\
\text { obtained relevant employment when } \\
\text { they decided to prolong their stay in } \\
\text { the Arctic. }\end{array}$ \\
\hline $\begin{array}{l}\text { Ahmed } \\
\text { (45) }\end{array}$ & $\begin{array}{l}\text { Refugee to } \\
\text { Norway, but } \\
\text { lifestyle migrant to } \\
\text { Finnmark. Married } \\
\text { to Anaïs. } \\
\text { Copreneurs from } \\
\text { Asia }\end{array}$ & $\begin{array}{l}\text { At arrival in } \\
\text { Finnmark }\end{array}$ & $\begin{array}{l}\text { Restaurant } \\
\text { (pizza, fast } \\
\text { food) }\end{array}$ & 5 yrs & 1 baby & Full partner & $\begin{array}{l}\text { Autonomy, } \\
\text { always a dream, } \\
\text { meaningful, } \\
\text { create a meeting } \\
\text { place }\end{array}$ & $\begin{array}{l}\text { He: no formal qualifications. She has } \\
\text { a craft certificate as a cook. He } \\
\text { obtained employment after finishing } \\
\text { the compulsory introductory } \\
\text { education for refugees in Oslo ( } 2 \\
\text { years) and thereafter took over a } \\
\text { corner shop there. He fell in love with } \\
\text { Finnmark when river fishing salmon } \\
\text { there. He and his wife moved } \\
\text { northwards soon after when they } \\
\text { found available restaurant premises. }\end{array}$ \\
\hline
\end{tabular}




\begin{tabular}{|c|c|c|c|c|c|c|c|c|}
\hline $\begin{array}{l}\text { Respond- } \\
\text { ents }\end{array}$ & $\begin{array}{l}\text { Migration \& family } \\
\quad \text { situation }\end{array}$ & $\begin{array}{l}\text { Time in rural } \\
\text { bef. start-up }\end{array}$ & Business & $\begin{array}{l}\text { Time in } \\
\text { rural }\end{array}$ & Children & $\begin{array}{l}\text { Role of } \\
\text { spouse }\end{array}$ & $\begin{array}{l}\text { Why becoming } \\
\text { entrepreneur? }\end{array}$ & Background and experience \\
\hline $\begin{array}{l}\text { Ali } \\
(30)\end{array}$ & Refugee from Asia & After 4 yrs & $\begin{array}{l}\text { Restaurant } \\
\text { (fast food } \\
\text { and local } \\
\text { Norwegian } \\
\text { food) }\end{array}$ & 9 yrs & - & $\begin{array}{l}\text { Recently got } \\
\text { married }\end{array}$ & $\begin{array}{l}\text { Autonomy, } \\
\text { flexibility, more } \\
\text { income, doing } \\
\text { something } \\
\text { meaningful }\end{array}$ & $\begin{array}{l}\text { No formal qualifications. He soon } \\
\text { obtained (informal) employment in } \\
\text { a pizza restaurant. After learning some } \\
\text { Norwegian and basic cooking skills, he } \\
\text { started a kebab cart. He later started } \\
\text { a restaurant serving both fast food and } \\
\text { traditional Norwegian dishes. }\end{array}$ \\
\hline $\begin{array}{l}\text { Julius } \\
\text { (45) }\end{array}$ & $\begin{array}{l}\text { Refugee from Asia. } \\
\text { Married to } \\
\text { a woman from } \\
\text { same country }\end{array}$ & After 15 yrs & $\begin{array}{l}\text { Restaurant } \\
\text { (fast food } \\
\text { and local } \\
\text { Norwegian } \\
\text { food) }\end{array}$ & 23 yrs & $\begin{array}{l}3 \\
\text { children, } \\
\text { kindergar } \\
\text { ten and } \\
\text { school }\end{array}$ & $\begin{array}{l}\text { Great } \\
\text { emotional } \\
\text { support }\end{array}$ & $\begin{array}{l}\text { Meaningful, } \\
\text { work-family } \\
\text { balance, show } \\
\text { that immigrants } \\
\text { are not } \\
\text { freeloaders }\end{array}$ & $\begin{array}{l}\text { He worked in the fish processing } \\
\text { industry and in different stores before } \\
\text { taking a 1-years education in massage } \\
\text { therapy and starting his own business. } \\
\text { His wife: no formal qualification and } \\
\text { does not work outside the home. }\end{array}$ \\
\hline $\begin{array}{l}\text { Mehmet } \\
\text { (35) }\end{array}$ & $\begin{array}{l}\text { Refugee from Asia. } \\
\text { Married to a } \\
\text { Norwegian woman }\end{array}$ & After 12 yrs & Garage & 14 & 1 baby & $\begin{array}{l}\text { Great } \\
\text { emotional } \\
\text { support, } \\
\text { main care } \\
\text { taker at } \\
\text { home }\end{array}$ & $\begin{array}{l}\text { Autonomy, } \\
\text { more money, } \\
\text { flexibility }\end{array}$ & $\begin{array}{l}\text { Craft certificate (mechanics) from country } \\
\text { of origin and from Norway. Worked as } \\
\text { a mechanic for several years before } \\
\text { starting his own garage in Finnmark } \\
\text { together with a Norwegian partner. }\end{array}$ \\
\hline $\begin{array}{l}\text { Paul } \\
\text { and } \\
\text { Pia } \\
\text { (45) }\end{array}$ & $\begin{array}{l}\text { He: refugee from } \\
\text { Africa. She: } \\
\text { dependent } \\
\text { migrant. } \\
\text { Copreneurs }\end{array}$ & After 3 yrs & $\begin{array}{l}\text { Corner shop } \\
\text { and café }\end{array}$ & 8 yrs & $\begin{array}{l}4 \\
\text { children, } \\
\text { school } \\
\text { and older }\end{array}$ & Full partner & $\begin{array}{l}\text { Making other } \\
\text { immigrants feel } \\
\text { more at home in } \\
\text { the north, } \\
\text { creating arenas } \\
\text { for intercultural } \\
\text { communication }\end{array}$ & $\begin{array}{l}\text { Both: No formal qualifications, but they ran } \\
\text { a book shop in the refugee camp before } \\
\text { migrating to Norway. After the } \\
\text { introductory course, he obtained part-time } \\
\text { jobs in the church and as a care worker. He } \\
\text { later started a corner shop. After family } \\
\text { reunification, his wife joined the business } \\
\text { full time, and they started a café together } \\
\text { in addition to the food shop. }\end{array}$ \\
\hline
\end{tabular}




\section{RESULTS AND DISCUSSION}

In this section, I will present the stories of three selected immigrant couples who started businesses in Finnmark. These stories illustrate processes and practices common to most of the participants. Whereas the two first couples came to Finnmark as lifestyle migrants, the last couple, Paul and Pia, came as a refugee and (some years later) as a dependent migrant, respectively.

\section{Found the Perfect Premises on the Internet and had to Go North}

Hilda and Hans came to Finnmark as lifestyle migrants from Western Europe. Since the 1990s, Hilda had regularly visited Norway, and since she met Hans in the early 2000s, they had spent several summer holidays together in the north of Norway ${ }^{2}$. Hilda explained, 'For many years, I felt that I had to go north during the summer holidays. If for some reason I couldn't go one year, my heart really hurt!' In 2007 , they made a first attempt to move to Norway, but neither of them found a job. However, as they already ran a small consultancy business together in their country of origin, they started to think of self-employment as a strategy that would allow them to settle in Finnmark and make a living there. As Hilda was 'good with people' and had some experience working in cafes and Hans excelled at cooking, they decided that running a small restaurant together as copreneurs was the option they would choose. One day they found the perfect restaurant premises for rent on the Internet. They responded to the advertisement, received the rental contract, and completed all the paperwork regarding the business start-up before relocating to Finnmark a few months later.

Although the transition from a city in Western Europe to a coastal community in Finnmark was significant, they immediately knew they had done the right thing in moving northwards. They felt at home in the north. They continued to work long hours as they did before, but they found their new lives enjoyable, not least due to the way they were received by people in the community. Only a couple of days after their arrival, local people began stopping by the restaurant premises to ask if they could help with anything. Hilda and Hans enthusiastically reported that the owner of the premises suggested they could decorate the restaurant with musical instruments, and when this idea was accepted, he had brought old musical instruments that were used for decoration. Another person suggested that they could organize occasional musical evenings, which turned out to be quite successful: 'You know, many people are so talented here', the smiling couple reported.

Some women in the community, moreover, assisted Hans, the chef, in developing the menu. From day one, Hilda and Hans had decided that they wanted to use local fresh fish and meat and to serve primarily traditional dishes from the region. Hans explained that before starting the business, he had purchased a Norwegian cookbook with traditional recipes and started experimenting. However, in the beginning, he noticed that the guests were not always quite happy with the dishes he served, making comments such as, 'That fish soup is from Bergen (in the south); we don't eat it that way here'. One of their regular guests, an elderly woman, offered help. She went through the cookbook together with Hans and explained what she believed people in the community would like

\footnotetext{
${ }^{2}$ Although they had visited northern Norway, they had never visited Finnmark and they did not know any people in Finnmark before moving northwards.
} 
and dislike. In addition, she brought old recipes from her own family and even showed Hans how to make some of these local dishes. For some days, Hilda laughed, Hans and the local elderly woman were in the kitchen together, experimenting and tasting. This mutual engagement was clearly another key to success. Hilda concluded, 'People are so open here. You can ask about anything, and they help if they can'.

\section{We Were Asked to Take Over the Firm}

Vidar and Vibeke were also lifestyle migrants from Western Europe and came to Finnmark ten years before our interview to do 'something exotic and different'. Vidar obtained employment in a private architectural firm in Finnmark, and Vibeke obtained a position in the municipality; a couple of years later, Vibeke took a job in the same firm as Vidar. One day, the owner of the firm revealed that she was planning to retire and invited Vidar and Vibeke to take over the firm, an invitation they accepted some months later.

At the time of the interview, they had run the firm together for a few years. Vidar explained that in addition to drawing houses particularly adapted to a northern climate, they were designing outdoor spaces in relation to kindergartens and elderly homes. Moreover, the couple had initiated several community projects in which they linked persons and activities related to northern cultures and landscapes by organizing cultural events and concerts in an abandoned industrial area. Another community project focused on the northern lights as a resource for outdoor experiences during the dark winter. Vidar, Vibeke and some of their employees had worked on that initiative in several ways, including by offering education to municipal advisors with regard to what type of artificial lighting should be used to prevent 'blinding' people. In addition, they participated in the construction of various 'gazing spots' in the community where tourists and other interested people could enjoy the northern lights particularly well.

The motivation for their engagement in the place through various place-making projects was to 'give something back to the people here', as Vidar phrased it. Moreover, Vidar and Vibeke were concerned about the value of knowing the northern culture to make houses and buildings that would 'fit into the communities'. Vidar explained:

'As architects, we think it is important to be close to people and cultures here, to know something about the north. In principle, you can sit anywhere designing buildings according to the guidelines of Norwegian law for housing and property, but in practice, it is of great value to be close to the people you are designing for in terms of knowing the place, the local culture, and not least the local climate.'

\section{Finally Got the Loan and Could Make a Difference}

Paul is originally from Africa. After fleeing war in his home region, he lived for several years in a refugee camp, where he ran a bookstore with his wife. Approximately ten years before our interview, he came to Finnmark with his oldest son, who was ten years old at the time, through the United Nations' (UN) refugee quota system. His wife, Mary, and their younger children were not given the same status in the UN system and had to remain behind. Arriving in Finnmark during the winter shocked Paul. He recalled:

'It was really hard in the beginning. I came in March. It was snowy, it was dark. It was a new experience. I came from a city of one million inhabitants directly to 
this small town with an unfamiliar language, an unfamiliar climate, and an unfamiliar culture; everything was unfamiliar. That was so hard.'

Paul explained, however, that he immediately began to make an effort to enjoy his new life in the North. He wanted to earn a good income so that he could apply for family reunification as soon as possible. He also wanted to improve the lives of other refugees in the community. Only weeks after his arrival, he launched an association for refugees and organized a gospel choir and a band. After a while, he also initiated a women's group in the church. These activities became popular with the refugees, local people and the local authorities. Quite often at seminars and meetings, Paul and his band or the choir would be invited to perform by the local and regional authorities.

Paul learned Norwegian and completed the compulsory introductory programme for refugees. He obtained part-time employment as a social care worker and a part-time position in a local church. Additionally, he wanted to start a retail shop that would serve other immigrants as well as the native population. Obtaining the loan to finance the start-up was the main challenge. With the help of a clerk in the municipality, however, he finally received a small loan from the bank. Paul opened his shop while keeping (but reducing) his two other jobs. His life was 'only work' at that time. However, although it was tiring, he enjoyed it. After four years, he fulfilled the economic requirements to apply for family reunification. Upon her arrival in Finnmark, Pia learned Norwegian and began to work in the international food shop; a couple of years later, they started a café that was intended to be a meeting place for immigrants and local people. As an entrepreneurial couple, Paul and Pia felt supported by local people and by other refugees. They had several part-time employees in their café and shop, including both their own adolescent children and local ethnic white youth. Paul's community engagement was appreciated and even rewarded with a local culture prize from the municipality. According to the local newspaper, Paul was the first immigrant ever to receive this award.

\section{Interpretation and Analysis}

The participants gave various reasons for having chosen to settle down in Finnmark. Several mentioned aspects related to the particular geographical setting. They talked about the calm environment, the clean and wild nature, the long and light summer, the northern lights, outdoor recreation opportunities, and feeling free and at home in the northern landscape. Daniela, for instance, said, 'Here, you have the ocean, the horizon, the infinity. You feel very free'. Eeva said that the open fjord made a 'fantastic impression' on her when she arrived in Finnmark as it was completely different from her previous experiences. Ahmed, who moved to Finnmark with his wife to start a pizzeria after having lived some years in Oslo, explained:

'I was on vacation here in 2007 , and I really liked what I saw. In addition, some of my friends lived here, and what's more, there was a pizza restaurant for sale here that I was interested in. So I bought the pizzeria, we sold everything in Oslo and settled in Finnmark. It was not only the business opportunity that made us move. We also like the natural environment and landscape here, both summer and winter. (...) Personally, I love fishing, I do that a lot (he particularly enjoyed salmon fishing in the river, he explained later in the interview). Otherwise, I just find it 
easier to live here than in the city. It's close to the wild nature here; it's easy to have fun outdoors and relax. I prefer that to the stress of a city such as Oslo.'

Creating and exploiting business opportunities in Finnmark typically involved doing something meaningful, interesting, fun and challenging. Some participants in addition talked about securing a steady income for themselves and their families. Moreover, entrepreneurship was about creating values not only for their family but also for other immigrants to make them feel at home in the north (Paul). It was about creating values for tourists by helping them experience the northern landscapes through ice diving, boat trips, fishing, king crab and whale safari (Vladimir) and for the local community by creating new meeting places (Ahmed, Paul, Vidar and Vibeke). Starting a business also involved aspects such as contributing to new understandings of immigrants as contributors to local development (Julius), offering something new and useful to the local community such as Chinese medicine and Asian holistic massage (Lars, Julius), and creating pride in local food (Hans and Hilda). These motivations may be partly explained by the social ties that the immigrants were about to develop with people in the local community in which they had settled.

\section{The Community Supporting the Immigrant Entrepreneurs}

As discussed in the introduction, the literature often assumes that long-term residence in a certain place and deep social relations with the community may be key to entrepreneurial success (Dahl \& Sorenson, 2009; Jack \& Anderson, 2002; McKeever, Jack \& Anderson, 2015). In this study, as opposed to most other studies that have explored the relationship between community/place and entrepreneurship processes in rural contexts, none of the participants (with one exception) were members of local families, none had attended local schools, and few had any social relations to people in the rural north before settling there. Nevertheless, upon their arrival in Finnmark, most participants were soon able to activate various resources. In fact, among the 11 households in this study, three started their businesses upon or shortly after their arrival, three of them within one to four years, and five of them after having stayed five years or more in Finnmark. The participants brought along their own human and economic capital, and a short time after settling in Finnmark, the local community embraced them and enabled them to act on their intentions by offering various kinds of support. Hence, both the entrepreneurs' own enactment with place and community and the community's engagement with the newcomers contributed to shaping and facilitating the process of becoming an entrepreneur in the rural north.

Immigrant entrepreneurs may not create the greatest economic value in Finnmark, and they may not employ many people, but in rural and sometimes depleted communities, they represent hope. By moving against the tide, these immigrants signal that they have faith in the future of Finnmark. Hence, the act of moving northwards and starting a business there seems to be interpreted in some communities in Finnmark as a gesture, or even as a gift. This finding may explain why some of the participants in this study were so well received, encouraged and supported as suggested in the case stories presented above. This article thus reveals that newcomers from a different cultural background even with limited acquaintance with the local language may be able to successfully create and exploit entrepreneurial opportunities, and that a key role in these cases is played by the rural community itself. Acceptance by the local community was apparent in many ways. The most evocative example is the story presented by Hans 
and Hilda, who settled in Finnmark to start a restaurant but with no clear concept. Once they arrived, various persons in the local community helped them with doing the decorations, developing the social programme (musical evenings) as well as the menu, and showed them where to purchase the best local fish. The other stories in this study are also quite intriguing in their own right. Several of the participants spoke about receiving assistance from people in the municipal administration (Daniela, Paul, Eeva). Moreover, Paul received the municipal culture prize for his various engagements, and Daniela was invited to produce the new mayor chain in her municipality some years ago. In general, the participants spoke of local approval and loyalty from the population who were interested in what they offered through their businesses, whether it was alternative treatments (Julius and Lars), new or familiar tastes through various cafés or restaurants (Ali, Ahmed, Paul and Pia, Hans and Hilda), painting and surface treatments (Eeva), or architectural services (Vibeke and Vidar). Thus, spatial embeddedness through social relations is crucial to entrepreneurial processes in this study of immigrant entrepreneurship in northernmost Norway. However, in contrast to some studies in the previous literature, I have shown that social relations in a local community do not have to be 'long term' or 'deep' to link the entrepreneurs to various local social resources.

\section{Immigrant Entrepreneurs Building Rural Regions}

Place and community were important to the participants in this study. Not only had the immigrants developed a sense of belonging in the north, but they also wanted to take part in local place development. Some started several firms, such as Daniela and Dieter, who ran not only the Arctic Glasstudio in Villa Borealia but also the local tourism office, the campground and the guesthouse in the community. The other participants also engaged in their new local community in various ways: they started a choir, a musical band and a women's group (Paul), and they started several community projects related to the reclaiming of abandoned locations (former industrial sites), cultural productions and viewing spots for northern lights (Vibeke and Vidar). They also engaged with the place on a personal basis using the northern landscapes for outdoor activities and recreation alone or together with family or friends, which seemed to strengthen their sense of belonging in the north (e.g., Vladimir, Eeva, Ahmed, Daniela). Hence, the participants gradually became spatially embedded in Finnmark through various social bonds, some of which were established upon their arrival whereas others developed over time. The participants were thus engaged in the community in various ways. Hence, as suggested by McKeever, Jack \& Anderson $(2015,59)$, the outcomes of rural entrepreneurship are not only 'extracting the community for self-serving purposes' but also entail a 'building process' of the rural place/community, both physically and mentally. As also found in McKeever, Jack \& Anderson (2015), my participants understood their relationship with the community in which they had settled in terms of mutuality or reciprocity. Thus, the participants engaged in the community and the place they had settled through entrepreneurship and other local practices and projects, and at the same time, the community engaged in them.

\section{CONCLUSIONS}

The literature exploring the spatial embeddedness of entrepreneurial processes in rural areas has often focused on 'local' or 'native' entrepreneurs who have lived in the region 
for long periods of time (Dahl \& Sorenson, 2009; McKeever, Jack \& Anderson., 2015). However, there is currently a growing strand of research that reveals how various groups of in-comers, including immigrants, become embedded and create businesses and thereby contribute to place development in the host society (Baycan-Levent \& Nijkamp, 2009; Jones, Ram, \& Theodorakopoulos, 2010; Miera, 2008; Ram, 1997). Whereas most of this research is based in highly urban contexts, a few recent studies explore immigrant entrepreneurship processes in rural contexts (Steinberg et al., 2010; Stone \& Stubbs, 2007; Zarrugh, 2007). In much of the entrepreneurship literature, however, the important connection between the entrepreneurs and the place in which they live and operate is generally not well understood, as also argued by Welter (2011). As mentioned in the introduction, Yeasmin (2016) argues for the relevance of using a triple disadvantage theory to make sense of immigrant entrepreneurship in Lapland in northern Finland. As this study is located in Finnmark in northernmost Norway, which is very close to Lapland, one could assume that the triple disadvantage theory would be relevant to analyze the findings in the present study, too. As I see it, this is not the case. The first disadvantage that Yeasmin puts forward is that immigrant entrepreneurs are pushed into entrepreneurship by necessity (Yeasmin, 2016, p. 133). In my study, however, the modes of entry are quite diverse as indicated previously (Munkejord, 2015a). Moreover, even in Yeasmin's study, it is an exaggeration to state that immigrant entrepreneurs in Lapland are 'mainly driven by necessity' as only $10 \%$ of her sample reported that they had been pushed to start a business due to unemployment (Yeasmin, 2016, p. 131). The second disadvantage that Yeasmin puts forward is that immigrant entrepreneurs, due to lack of local knowledge and poor skills in the native language, are not able to take advantage of their competence and capacities (Yeasmin, 2016, p. 134). This may very well be the case, and in this article, I have addressed this issue in terms of immigrants' lack of spatial embeddedness in the new region where the settle. However, this article shows that, in some cases, social relations and collaboration between the immigrant entrepreneur and people in the local community may overcome this initial disadvantage. The third advantage that Yeasmin puts forward is that rural regions (such as Lapland and Finnmark) in themselves represent a disadvantage for immigrant entrepreneurs because there are so few immigrants from each country there, so that the immigrant entrepreneurs cannot easily make a living out of serving their ethnic community only (Yeasmin, 2016, p. 134). As I see it, Yeasmin is right about the fact that many rural areas in the West are sparsely populated, and that immigrant populations there are thin and dispersed. But, it is a misunderstanding to assume that immigrant entrepreneurs are only interested in serving their ethnic community. Munkejord (2015a) on the contrary reveals that some immigrant entrepreneurs in rural Norway are interested in serving the mainstream marked from day one, and hence that a thin and dispersed immigrant population does not necessarily represent a disadvantage for nascent or operating rural immigrant entrepreneurs. Rather, as this article indicates, the majority population may be interested in supporting immigrant entrepreneurs who settle in sparsely populated areas and their start-up initiatives may be interpreted positively as a contribution to local place development. Hence, when being supported by the rural community, immigrants may be able to successfully create and exploit entrepreneurial opportunities in rural communities, and, through entrepreneurship processes, they may even contribute to (re)build rural regions. 


\section{Future Research}

This article examines immigrant entrepreneurship in what can be considered an extreme case. Although similar patterns may emerge in other rural or remote contexts, it would be useful for future research to examine the same research questions among different groups of immigrant entrepreneurs in rural and urban, as well as in depleted and prosperous contexts. There are limitations to this study in relation to the geographical focus (one rural area in one country) and the limited number of participants. The findings, however, offer suggestive insights into connections among immigrant entrepreneurs, place and community and how the spatial embeddedness of entrepreneurship processes may take shape.

\section{REFERENCES}

Aldrich, H.E., \& Waldinger, R. (1990). Ethnicity and entrepreneurship. Annual Review of Sociology, 16(1), 111-135.

Anderson, A.R. (2000). Paradox in the periphery: an entrepreneurial reconstruction? Entrepreneurship and Regional Development, 12(1), 91-109.

Baycan-Levent, T., \& Nijkamp, P. (2009). Characteristics of migrant entrepreneurship in Europe. Entrepreneurship and Regional Development, 21(4), 375-397.

Berg, N.G., \& Dale, B. (2004). Sted - begreper og teorier. In N. G. Berg, B. Dale, H. K. Lysgård, \& A. Løfgren (Eds.), Mennesker, steder og regionale endringer. Trondheim: Tapir Akademisk Forlag.

Brown, R. (2000). Clusters, Supply Chains and Local Embeddedness in Fyrstad. European Urban and Regional Studies, 7(4), 291-305.

Charmaz, K. (1995). Grounded Theory. In J. A. Smith, R. Harré, \& L. Van Langenhove (Eds.), Rethinking Methods in Psychology (pp. 27-49). London, Thousand Oaks, New Dehli: Sage.

Cohen, A.P., \& Rapport, N. (1995). Introduction: consciousness in anthropology. In A. P. Cohen \& N. Rapport (Eds.), Questions of Consciousness (pp. 1-18). London \& New York: Routeledge.

Dahl, M., \& Sorenson, O. (2009). The embedded entrepreneur. European Management Review, 6(3), 172-181.

Dahl, M.S., \& Sorenson, O. (2007). Home sweet home: Social capital and location choice. Working paper published online: http://www.google.no/url?sa=t\&rct=j\&q=\&esrc=s\&frm=1\&source=web\&cd=1\& ved=0CBOQFjAA\&url=http\%3A\%2F\%2Fwww.druid.dk\%2Ffileadmin\%2Fimages\%2Fdokumenter\%2FS orenson.pdf\&ei=hA6NVc2FLIrWygOI34-ICQ\&usg=AFQjCNEfgkbZE16ZDuFjtO0QxtPoaRkNHw

Dana, L.-P. (Ed.) (2007). Handbook of Research on Ethnic Minority Entrepreneurship. Cheltenham, Massachusetts: Edward Elgar Publishing.

Gartner, W.B. (2007). Entrepreneurial narrative and a science of the imagination. Journal of Business Venturing, 22(5), 613-627.

Granovetter, M.S. (1985). Economic action and social structure: the problem of embeddedness. American Journal of Sociology, 91(3), 481-510.

Halfacree, K.H. (1995). Talking about rurality: Social representations of the rural as expressed by residents of six English parishes. Journal of Rural Studies, 11(1), 1-20.

Halfacree, K.H. (2004). Rethinking 'Rurality'. In T. Champion \& G. Hugo (Eds.), New forms of Urbanization. Beyond the Urban-Rural Dichotomy (pp. 285-304). Aldershot, Burlington: Ashgate.

Jack, S., \& Anderson, A.R. (2002). The effects of embeddedness on the entrepreneurial process. Journal of Business Venturing, 17(5), 476-487. 
Jones, T., Ram, M., \& Theodorakopoulos, N. (2010). Transnatonalism as a force for ethnic minority enterprise? The case of Somalis in Leicester. International Journal of Urban and Regional Research, 34(3), 565-585.

Kalantaridis, C. (2006). A study into the localization of rural businesses in five European countries. European Planning Studies, 14(1), 61-78.

Kalantaridis, C. (2010). In-migration, entrepreneurship and rural-urban interdependencies: The case if East-Cleveland, North East England. Journal of Rural Studies, 26(4), 418-427.

Kloosterman, R.C., \& Rath, J. (2001). Immigrant entrepreneurs in advanced economies: Mixed embeddedness further explored. Journal of Ethnic and Migration Studies, 27(2), 189-201.

Kraft, S.E. (2008). Place-making through Mega-Events. In J. O. Bærenholdt \& B. Granås (Eds.), Mobility and Place. Enacting Northern European Peripheries. (pp. 219-231). Aldershot: Ashgate.

Liepins, R. (2000). Exploring rurality through 'community': discources, practices and spaces shaping Australian and New Zealand rural 'communities'. Journal of Rural Studies, 16(3), 325-341.

Massey, D. (1994). Space, place and gender. Cambridge: Polity Press.

McKeever, E., Anderson, A., \& Jack, S. (2014). Entrepreneurship and mutuality: social capital in processes and practices. Entrepreneurship and Regional Development, 26(5-6), 453-477.

McKeever, E., Jack, S., \& Anderson, A.R. (2015). Embedded entrepreneurship in the creative reconstruction of place. Journal of Business Venturing, 30(1), 50-65.

Miera, F. (2008). Transnational strategies of Polish migrant entrepreneurs in trade and small business in Berlin. Journal of Ethnic and Migration Studies, 34(5), 753-770.

Morawska, E. (2004). Immigrant transnational entrepreneurs in New York. Three varieties and their correlates. International Journal of Entrepreneurial Behaviour \& Research, 10(5), 325-348.

Munkejord, M.C. (2014). Stories of Butterflies in Winterland: Representations of Northern Coastal Realities in Norway. In G. Bonifacio (Ed.), Gender and Rural Migration. Realities, Conflict and Change (pp. 23-41). New York \& Oxon: Routledge.

Munkejord, M.C. (2015a). Local and transnational networking among female immigrant entrepreneurs in peripheral rural contexts: perspectives on Russians in Finnmark, Norway. European Urban and Regional Studies, 24(1), 1-14, DOI: 10.1177/0969776415587122

Munkejord, M.C. (2015b). Modes of entry to male immigrant entrepreneurship in a rural context: Start-up stories from Northern Norway. Entrepreneurial and Business Economics Review, 3(3), 145-162. doi:10.15678/EBER.2015.030308

O'Reilly, K., \& Benson, M. (2009). Lifestyle Migration: Escaping to the Good Life? In M. Benson \& K. O'Reilly (Eds.), Lifestyle Migration. Expectations, Aspirations and Experiences. (pp. 1-14). Farnham, Burlington: Ashgate.

Panelli, R. (2006). Rural society. In P. Cloke, T. Marsden, \& P. H. Mooney (Eds.), Handbook of Rural Studies (pp. 63-90). London, Thousand Oaks, New Dehli: Sage.

Portes, A., \& Jensen, L. (1989). The enclave and the entrants: Patterns of ethnic enterprise in Miami before and after Mariel. American Sociological Review, 54(6), 929-949.

Portes, A., \& Zhou, M. (1996). Self-employment and the Earnings of Immigrants. American Sociological Review, 61(2), 219-230.

Ram, M. (1997). Ethnic minority enterprise: an overview and research agenda. International Journal of Entrepreneurial Behaviour \& Research, 3(4), 149-156.

Ram, M., \& Jones, T. (2008). Ethnic minority businesses in the UK: An overview. Migracões, 3, 61-71.

Riley, R. (2000). Embeddedness and the Tourism Industry in the Polish Southern Uplands: Social Processes as an Explanatory Framework. European Urban and Regional Studies, 7(3), 195-210. 
Romo, F.P., \& Schwartz, M. (1995) Structural embeddedness of business decisions: A sociological assessment of the migration behavior of plants in New York State between 1960 and 1985, American Sociological Review, 60(5): 874-907.

Smart, J. (2003). Ethnic Entrepreneurship, Transmigration, And Social Integration: An Ethnographic Study Of Chinese Restaurant Owners In Rural Western Canada. Urban Anthropology and Studies of Cultural Systems and World Economic Development, 32(3-4), 311-342.

Steinberg, S.L., Steinberg, S.J., Eschker, E., Keeble, S.M., \& Barnes, J.M. (2010). Rural Ethnic Entrepreneurship. A Spatial Networks Approach to Community Development. California Center for Rural Policy and Institute for Spatial Analysis, Humboldt State University, Arcata, CA.

Steyaert, C., \& Katz, J. (2004). Reclaiming the space of entrepreneurship in society: geographical, discursive and social dimensions. Entrepreneurship and Regional Development, 16(3), 179-196.

Stone, I., \& Stubbs, C. (2007). Enterprising expatriates: lifestyle migration and entrepreneurship in rural southern Europe. Entrepreneurship and Regional Development, 19(5), 433-450.

Storti, L. (2014). Being an entrepreneur: emergence and structuring of two immigrant entrepreneur groups. Entrepreneurship and Regional Development, 26(7-8), 521-545.

Uzzi, B. (1997). Social structure and competition in interfirm networks: the paradox of embeddedness. Administrative Science Quarterly, 42(1), 35-68.

Waldinger, R. (1994). The making of an immigrant niche. International Migration Review, 28(1), 3-30.

Welter, F. (2011). Contextualizing Entrepreneurship - Conceptual Challenges and Ways Forward. Entrepreneurship, Theory \& Practice, 35(1), 165-184.

White, M.C. (2004). Inward Investment, Firm Embeddedness and Place: An Assessment of Ireland's Multinational Software Sector. European Urban and Regional Studies, 11(3), 243-260.

Xheneti, M., Smallbone, D., \& Welter, F. (2013). EU enlargement effetcs on cross-border informal entrepreneurial activities. European Urban and Regional Studies, 20(3), 314-328.

Yeasmin, N. (2016). The Determinants of Sustainable Entrepreneurship of Immigrants in Lapland: An Analysis of Theoretical Factors. Entrepreneurial Business and Economics Review, 4(1). doi:10.15678/EBER.2016.040109

Zarrugh, L.H. (2007). From workers to owners: Latino entrepreneurs in Harrisonburg, Virginia. Human Organization, 66(3), 240-248. 


\section{Author}

\section{Mai Camilla Munkejord}

Research Professor at Uni Research Rokkan Centre and Professor in Social Sciences, UiT the Arctic University of Norway.

Correspondence to: Mai Camilla Munkejord, P. Box 7810, 5020 Bergen, Norway, e-mail: Mai.Munkejord@uni.no

\section{Acknowledgements and Financial Disclosure}

This study is part of a research project headed by professor Einar Rasmussen, UiN, entitled "Border-crossing business activity in the Barents Region: Understanding the drivers and barriers for transnational entrepreneurship" (2012-2015). This project was financed by the Norwegian Research Council, grant number 212361 as well as by the former Finnmark University College, Norway (now UiT, the Arctic University of Norway).

Many thanks to colleagues and to the anonymous reviewers and the editor in EBER for valuable comments to an earlier version of this article.

\section{Copyright and License}

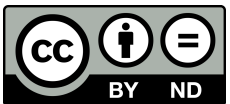

This article is published under the terms of the Creative Commons Attribution - NoDerivs (CC BY- ND 4.0) License http://creativecommons.org/licenses/by-nd/4.0/

\section{Published by the Centre for Strategic and International Entrepreneurship - Krakow, Poland}

